Original Article

\title{
Use of homeopathic Arnica montana for the issuance of roots of Rosmarinus officinalis L. and Lippia alba (Mill) N.E.Br.
}

\author{
Filipe Pereira Giardini Bonfim ${ }^{1}$; Ernane Ronie Martins (PhD)2; \\ Rosana Gonçalves Rodrigues das Dores(PhD) ${ }^{3}$; Camila Karen Reis Barbosa²; \\ Vicente Wagner Dias Casali(PhD)ํㅜㄹ Isabela Cristina Gomes Honório²
}

1 - Universidade Federal de Viçosa, MG, Brazil; 2 - Universidade Federal de Minas Gerais, MG, Brazil; 3 - Universidade Federal de Ouro Preto, MG, Brazil.

\begin{abstract}
This study sought to evaluate the influence of dilutions of the homeopathic preparation Arnica montana on the rooting of rosemary (Rosmarinus officinalis) and white Lippia (Lippia alba). Cuttings of R. officinalis and Lippia alba were place for rooting in trays of commercial substrate "plantmax"-like and soon after, subjected to daily applications of Arnica montana $3 \mathrm{cH}, 6 \mathrm{cH}, 9 \mathrm{cH}$ and $12 \mathrm{cH}$ and two controls - distilled water and ethanol $70 \%$. Statistical design was entirely casualized delineation, with 6 treatments and 4 repetitions, each experimental unit was composed by 10 stakes. Applications were made via pulverization, 10 drops of the treatment in $400 \mathrm{ml}$ of water. 45 days later the number of roots, the number of shoots, the length of the largest root, the percentage of sets and the quality of stakes were assessed. Data were analyzed through variance analysis, mean were compared by Tukey's test at 5\% level of statistical significance. Arnica montana $3 \mathrm{cH}, 6 \mathrm{cH}$ and $12 \mathrm{cH}$ had a stimulatory effect on all variables regarding the issuance of roots in both species studied, showing the similarity of this homeopathic preparation to the physiological picture arising from the process of cutting, promoting an increase in the percentage and quality of roots.
\end{abstract}

Keywords: Homeopathy; rooting; cutting; Arnica Montana

\section{Introduction}

The commercial production of medicinal plants in Brazil has not yet been fully exploited; most species are still illegally acquired in the forests, lowland, Cerrado and fields [1], resulting, thus, in the exhaustion of vegetal raw materials. Actions such as management and cultivation of medicinal plants are needed in order to check the effects of this predatory extractivism.

Rosemary (Rosmarinus officinalis L.) and white Lippia, "colic mint" (Lippia alba Mill), traditionally used in health programs, are important to poor populations, as their pharmacological actions are effective and safe.
Nevertheless, cultivation of medicinal plants requires the knowledge of their ways of propagation, adaption to environment, growth, development and aging [2].

Studies regarding the vegetative propagation of medicinal species, efficiently addressing social, economic and ecologic features are still relatively unknown, making organic production of vegetal matter difficult.

The use of alternative agriculture techniques, protecting the environment and resulting in high quality products at the same time, is the main challenge for those caring for quality of life.

In this context, the study of diluted and agitated solutions (homeopathy) may be relevant [3]. Tests of 
the use of homeopathy in plants are being conducted worldwide [4], showing positive results regarding the increase of the resistance to plagues and diseases [5], tolerance to improper conditions, blossoming, breaking of the of the seeds latency and production of healthy seedlings [6].

Arnica montana is homeopathically indicated to organisms exhibiting defensive behavior and hypersensitiveness in traumatic conditions or situations [7]. It is indicated in adaptation instances, adaptation impact, including physical and mechanical, old, inherited impacts, physical stress, sensitiveness to external factors, injuries, healing of tissues internally or externally damaged, [8] all these similar to the processes applied to plants in the process of cutting, i.e. physical stress due to cuts in stakes (injury). Arnica montana would act directly on the rooting of vegetal species [9]. Thus, it is paramount to test the mode of use and the efficacy of homeopathic preparations on the rooting of medicinal species, allowing for a characterization of the homeopathic potential of Arnica montana in different dilutions in this context.

The present study aimed to evaluate the influence of different dilutions of Arnica montana on the rooting of rosemary and white Lippia.

\section{Materials and Methods}

Two trials were conducted at the Center of Agrarian Sciences of the Federal University of Minas Gerais at Montes Claros, Minas Gerais, Brazil (NCA/UFMG), in a greenhouse; a same methodology was adopted in both cases, difference concerned the species under study: rosemary - from April 15 th to May $30^{\text {th }}$, 2007, and white Lippia - from September $1^{\text {st }}$ to October, $15^{\text {th }}, 2007$.

Stakes of rosemary and white Lippia were collected at the Medicinal Botanic Garden of NCA/UFMG, from the apical part of branches of uniform matrix plants. Stakes were placed to root in trays of a commercial substrate "plantmax"-like and were immediately subjected to daily applications of Arnica montana $3 \mathrm{cH}, 6 \mathrm{cH}, 9 \mathrm{cH}$ and $12 \mathrm{cH}$, and 2 controls, no agitated distilled water and ethanol $70 \%$ - these were the treatments in this study.

The statistical design was entirely casualized delineation, with 6 treatments and 4 repetitions, each experimental unit consisted of 10 stakes. Applications were made via pulverization, 10 drops in $400 \mathrm{ml}$ of water. The study was double-blind, symbols were employed to name each treatment in order to avoid possible interferences.

The homeopathic preparations were prepared at the Homeopathic Laboratory of the Phytotechnics Department of the Federal University of Viçosa, Minas Gerais, Brazil, according with the official national prescription [10]: 1 drop of mother tincture of Arnica montana was dissolved in 99 drops of alcohol 70\%, following the centesimal Hahnemannian scale $(\mathrm{cH})$.

45 days later, the number of roots (NROOT), shoots, length of the largest root (LROOT) in $\mathrm{mm}$, percentage of rooted stakes (PROOT), quality of the stakes (QUALY) and number of shoots of White Lippia (NSH) were evaluated. Quality of stakes was assessed by grading (0 to 5 ) by two independent raters. Data were interpreted through variance analysis and the means were compared through Tukey's test at 5\% level of statistical significance.

\section{Results and Discussion}

\section{Rosemary}

The treatments promoted significant differences in the variables LROOT, QUALY, PROOT, with the exception of NROOT. (Table 1)

Controls - distilled water and ethanol 70\% - did not show difference between them in all assessed variables, but did different from the homeopathic treatments in some of them (LROOT, QUALY and PROOT), which allows to infer that the observed effects were exclusively due to Arnica montana. NROOT did not show significant difference (Table 2 ), although Arnica montana $6 \mathrm{cH}$ and $12 \mathrm{cH}$ showed a tendency to higher mean values.

Regarding LROOT, the pathogenetic effect of Arnica montana $9 \mathrm{cH}$ may only be visually observed, with a mean lower than the other treatments and similar to the controls and Arnica montana $12 \mathrm{cH}$ (Table 2).

A similar result was observed [3] when the fresh mass of the air part of lemongrass (Cymbopogon citratus) of plants treated with dilutions of Sulphur was evaluated: lower mean values were recorded with dilution $30 \mathrm{cH}$, verifying, this, the pathogenetic effect of the variable fresh mass.

The differential action of Arnica montana $9 \mathrm{cH}$ could be observed in QUALY and PROOT, where the treatment does not differ from the control, showing lower mean values than the other dilutions.

Table 1. Variance analysis of variables: number of roots (NROOT), length of root (LROOT), quality of rooting (QUALY) and percentage of rooting (PROOT) in rosemary plants subjected to different solutions of Arnica Montana. 


\begin{tabular}{|c|c|c|c|c|c|}
\hline Treatment & 5 & $\begin{array}{l}\operatorname{NROOT}^{(1)} \\
2,84\end{array}$ & $\begin{array}{l}\text { LROOT } \\
461,6^{* *}\end{array}$ & $\begin{array}{l}\text { QUALY } \\
1,35^{* *}\end{array}$ & $\begin{array}{l}\operatorname{PROOT}^{(2)} \\
0,37^{* *}\end{array}$ \\
\hline Residue & 18 & 0,74 & 26,2 & 0,18 & 0,059 \\
\hline Total & 23 & & & & \\
\hline \multicolumn{2}{|c|}{ Coeffcient of Variation (\%) } & 39,8 & 43,1 & 47,7 & 18,0 \\
\hline
\end{tabular}

Table 2. Mean values of variables number of roots (NROOT), length of root (LROOT), quality of rooting (QUALY) and percentage of rooting (PROOT) in rosemary plants subjected to different dilutions of Arnica montana.

\begin{tabular}{|c|c|c|c|c|}
\hline Treatments & NROOT & LROOT & QUALY & PROOT \\
\hline Alcohol $70 \%$ & $1,54 \mathbf{a}$ & $3,48 \quad \mathbf{b}$ & $0,25 \mathrm{~d}$ & $0,34 \quad \mathbf{c}$ \\
\hline Distilled water & $1,29 \mathbf{a}$ & $5,37 \quad \mathbf{b}$ & 0,49 bcd & 0,59 bc \\
\hline Arnica montana $3 \mathrm{cH}$ & 2,69 a & $26,12 \mathbf{a}$ & 1,23 abc & $1,00 \mathbf{a b}$ \\
\hline Arnica montana $6 \mathrm{cH}$ & $3,02 \mathbf{a}$ & $24,20 \mathbf{a}$ & 1,61 a & 1,15 a \\
\hline Arnica montana $9 \mathrm{cH}$ & $1,38 \mathbf{a}$ & $1,57 \quad \mathbf{b}$ & 0,41 cd & 0,59 bc \\
\hline Arnica montana $12 \mathrm{cH}$ & $3,04 \mathbf{a}$ & $10,40 \mathbf{b}$ & $1,39 \mathbf{a b}$ & $0,91 \mathbf{a b}$ \\
\hline
\end{tabular}

Mean values followed for at least a same low case letter, in a column, do not differ significantly in Tukey's test at $5 \%$ level of statistical significance.

In the same variable (LROOT) it is possible to verify the differential effect of each dilution: Arnica montana $3 \mathrm{cH}$ and $6 \mathrm{cH}$ resulted in mean values 16.6 and 15.4 times, respectively, than $9 \mathrm{cH}$, which shows the non linearity of responses as a function of dilution. Significant increases were seen [11] in the height of plants of Justicia pectoralis when subjected to treatment with Arnica montana $3 \mathrm{cH}$.

In our study, treatment with Arnica montana $6 \mathrm{cH}$ also exhibited statistically significant higher mean values regarding controls in variables QUALY and PROOT (Table 2).
This treatment showed stimulatory effects in all variables regarding the issuance of roots in rosemary, thus it may be effectively used in the propagation of the species, as it resulted in higher quality roots.

\section{White Lippia}

Treatments promoted significant differences in variables NSH, LROOT, QUALY and PROOT, with the exception of NROOT (Table 3).

Table 3. Variance analysis of variables: number of roots (NROOT), number of shoots (NSH), length of root (LROOT), quality of rooting (QUALY) and percentage of rooting (PROOT) in white Lippia plants subjected to different dilutions of the homeopathic preparation Arnica montana.

\begin{tabular}{|c|c|c|c|c|c|c|}
\hline \multirow{2}{*}{ Variations sources } & \multicolumn{6}{|c|}{ Degress off Mean Squares } \\
\hline & Freedon & $\operatorname{NROOT}^{(1)}$ & $\mathrm{NSH}^{(1)}$ & LROOT & QUALY & $\operatorname{PROOT}^{(2)}$ \\
\hline Treatment & 5 & 2,79 & $0,54 * *$ & $10184^{* *}$ & $4,07^{* *}$ & $0,224^{*}$ \\
\hline Residue & 18 & 0,44 & 0,013 & 827.2 & 0,30 & 0,042 \\
\hline Total & 23 & & & & & \\
\hline \multicolumn{2}{|c|}{ Coeffcient of Variation (\%) } & 26,96 & 9,67 & 28.87 & 26,93 & 20,68 \\
\hline
\end{tabular}

Table 4. Mean values of variables number of roots (NROOT), number of shoots (NSH), length of root (LROOT), quality of rooting (QUALY) and percentage of rooting (PROOT) in white Lippia plants subjected to different dilutions of the homeopathic preparation Arnica montana.

\begin{tabular}{l|l|l|l|l|l}
\hline Treatments & NROOT & SNH & LROOT & QUALY & PROOT \\
\hline Alcohol $70 \%$ & 3,00 a & $1,02 \mathbf{b}$ & $45,63 \quad \mathbf{c}$ & $1,07 \mathbf{c}$ & $0,78 \mathbf{b}$
\end{tabular}




\begin{tabular}{l|l|l|l|l|l|l} 
Distilled water & $3,38 \mathbf{a}$ & $0,79 \mathbf{b}$ & $46,09 \mathbf{c}$ & $1,05 \mathbf{c}$ & $0,82 \mathbf{b}$ \\
Arnica montana $3 \mathrm{cH}$ & $4,64 \mathbf{a}$ & $1,40 \mathbf{a}$ & $136,92 \mathbf{a b}$ & $2,75 \mathbf{a}$ & $1,08 \mathbf{a b}$ \\
Arnica montana $6 \mathrm{cH}$ & $4,94 \mathbf{a}$ & $1,57 \mathbf{a}$ & $171,91 \mathbf{a}$ & $3,55 \mathbf{a}$ & $1,40 \mathbf{a}$ \\
Arnica montana $9 \mathrm{cH}$ & $3,01 \mathbf{a}$ & $0,77 \mathbf{b}$ & $85,66 \mathbf{b c}$ & $1,50 \mathbf{b c}$ & $0,84 \mathbf{b}$ \\
Arnica montana $12 \mathrm{cH}$ & $3,95 \mathbf{a}$ & $1,54 \mathbf{a}$ & $111,36 \mathbf{b}$ & $2,35 \mathbf{a b}$ & $1,05 \mathbf{a b}$ \\
\hline
\end{tabular}

Mean values followed for at least a same low case letter, in a column, do not differ significantly in Tukey's test at 5\% level of statistical significance.

Controls distilled water and ethanol $70 \%$ are statistically similar to each other in all variables studied; this allows inferring that the vehicle does not interfere in the manipulation of homeopathic preparations. Alterations in observations, thus, would be exclusively due to the homeopathic preparation Arnica montana. Variable NROOT showed no significant difference. (Table 4)

The effect of several dilutions of Arnica montana on several factors related to the growth and development of feverfew (Tanacetum parthenium) showed higher heights with decimal dilutions $1 \mathrm{x}$ and $5 \mathrm{x}$ and significant increase in fresh mass with dilutions $1 \mathrm{x}, 2 \mathrm{x}, 4 \mathrm{x}$ and $5 \mathrm{x}$ [12].

The effect of Arnica montana 9cH was not different from the controls' in any of the variables under study, showing lower mean values on variable NSH, which represents an inhibitory effect, and characterizes a pathogenetic effect. A similar result was obtained when beet (Beta vulgaris L.) was subjected to treatment with Phosphorus $1 \mathrm{cH}, 2 \mathrm{cH}$, $3 \mathrm{cH}, 4 \mathrm{cH}, 5 \mathrm{cH}$ and $6 \mathrm{cH}$ : lower values were observed in all variables related to the root by comparison to control [3].

Arnica montana $3 \mathrm{cH}, 6 \mathrm{cH}$ and $12 \mathrm{cH}$ have homeopathic effect regarding the issuance of roots, optimizing rooting in the species under study (white Lippia) and increasing the quality of the roots in the stakes.

\section{Conclusions}

Arnica montana in dilutions $3 \mathrm{cH}, 6 \mathrm{cH}$ and $12 \mathrm{cH}$ showed stimulatory effect in all variable related to issuance of roots in the species under study (rosemary and white Lippia), showing its similarity to the pathologic picture arising from the process of cutting, promoting an increase in the percentage and quality of roots.

\section{References}

[1] Guião M, Lamster E, Rocha D, Nogueira ACO, Lana JM. Plantas medicinais: cultivo, utilidades e comercialização. Belo Horizonte: EMATER-MG/PróRenda Rural-MG, IEF-MG; 2004.
[2] Reis MS, Mariot A. Diversidade natural e aspectos agronômicos de plantas medicinais. In: Simões CMO, Schenckel EP, Gosmann G, Mello JCP, Mentz LA, Petrovick PR, editors. Farmacognósia: da planta ao medicamento. Porto Alegre/Florianópolis: Universidade UFRS/Ed UFSC; 1999.

[3] Castro DM. Preparações homeopáticas em plantas de cenoura, beterrava, capim limão e chambá [Thesis Doctorate]. Viçosa: Universidade Federal de Viçosa; 2000.

[4] Duarte ESM. Soluções homeopáticas, crescimento e produção de compostos bioativos em Ageratum conyzoides L (Asteraceae) [Dissertation Master]. Viçosa: Universidade Federal de Viçosa; 2003.

[5] Khanna KK, Chandra S. Control of tomato fruit rot caused by Fusarium roseum with homeopathic drugs. Indian Phytopath. 1976; 29: 269-272.

[6] Arenales MC. Utilização da homeopatia na agropecuária. Proceedings of Encontro Mineiro sobre Produção Orgânica de Hortaliças; 1998; Viçosa, Brazil. Viçosa: Universidade Federal de Viçosa; 1998. 54-56.

[7] Marks C. Homeopatia: guia prático. São Paulo: Callis; 1997.

[8] Voisin H. Manual de matéria médica para o clínico homeopata. 2nd ed. São Paulo: Andrei; 1987.

[9] Kaviraj VD. Homoeopathy for farm and garden: toward a homoeopathic agriculture. [s.l.]: Mark Moodie; 2006.

[10] Farmacopéia Homeopática Brasileira. São Paulo: Andrei; 1977.

[11] Andrade FMC. Homeopatia no crescimento e produção de cumarina em chambá Justicia pectoralis Jacq [Dissertation Master]. Viçosa: Universidade Federal de Viçosa; 2000.

[12] Carvalho LM, Casali VWD, Cecon PR. Efeito de potências decimais da homeopatia de Arnica 
montana sobre plantas de Artemísia. Rev Bras Pl

Med. 2003; 6: 46-50.

\section{(cc) EY-NC-ND Licensed to GIRI}

Support: authors declare that this study received no funding

Conflict of interest: authors declare there is no conflict of interest

Received: 06 June 2008; Revised 19 June 2008; Published: 30 June 2008

Erratum: 30 Dec 2008. (http://www.feg.unesp.br/ ojs/zacha_ijhdr/erratum/?v=7\&i=23\&pi=113)

Correspondence author: Filipe Pereira Giardini Bonfim, email: filipegiardini@yahoo.com.br.

How to cite this article: Bonfim FPG, Martins ER, Dores RGR, Barbosa CKR, Casali VWD, Honório ICG. Use of homeopathic Arnica montana for the issuance of roots of Rosmarinus officinalis L. and Lippia alba (Mill) N.E.Br. Int J High Dilution Res [online]. 2008 [cited YYYY Mmm DD]: 7(23); 113-117. Available from: http://www.feg.unesp.br/ ojs/index.php/ijhdr/article/view/276/348. 